\title{
Post transplantation human herpes virus-8 unrelated primary effusion lymphoma of the peritoneal cavity in a HIV-negative female
}

\author{
I. Venizelos ${ }^{1}$, D. Tamiolakis ${ }^{2}$, M. Menegaki ${ }^{3}$, S. Nikolaidou ${ }^{2}$, S. Bolioti² ${ }^{2}$ C. Simopoulos ${ }^{4}$, N. Papadopoulos ${ }^{3}$
}

\section{Summary}

Primary effusion lymphoma (PEL) is a recently individualized form of non-Hodgkin lymphoma (WHO classification), developing mainly in HIV-infected males, more frequently homosexual, in advanced stages of the disease (total CD4+ lymphocyte count below 100-200/ $\mu 1$ ). Occasionally, it appears in other immunosupressive states (such as solid organs transplantation period) and even, although very rarely, in immunocompetent patients. From a pathogenic point of view, PEL has been related to Kaposi's sarcoma associated herpes virus (also named human herpesvirus 8, HHV 8) and to clinical antecedents of Kaposi's sarcoma. The relatively low frequency of this disease, the absence of a wide casuisticsts allowing a better characterization, and its unfavourable outcome, support the need of a deeper knowledge. We present here the clinico-biological findings of a HIV-negative patient, who was diagnosed of peritoneal PEL, of T cell origin, and not HHV 8-associated, five years after renal transplantation.

Key words: Primary effusion lymphoma (PEL). Non-Hodgkin lymphoma.

Oncología, 2005; 28 (5):258-261

\footnotetext{
${ }^{1}$ Department of Pathology. Ippokration Hospital of Salonica

${ }^{2}$ Department of Cytology. General Hospital of Chania

${ }^{3}$ Department of Histology - Embryology. Democritus University of Thrace, Greece

${ }^{4}$ Department of Surgery. Democritus University of Thrace, Greece
} 


\section{Resumen}

El linfoma de derrame primario (PEL) es una forma individualizada recientemente de linfoma no hodgkiniano (clasificación de la OMS), que se desarrolla principalmente en varones infectados con HIV, más frecuentemente homosexuales, en estadios avanzados de la enfermedad (recuento total de linfocitos CD+100-200/ $\mu$ l). Ocasionalmente aparece en otros estados de inmunosupresión (como durante el período de trasplante de órganos sólidos) e incluso, aunque muy rara vez, en pacientes inmunocompetentes. Desde un punto de vista patogénico, el PEL se ha relacionado con el herpesvirus asociado al sarcoma de Kaposi (también llamado herpesvirus 8 humano y HHV 8) y antecedentes clínicos de sarcoma de Kaposi. La frecuencia relativamente baja de la enfermedad, la ausencia de una casuística que permita una mejor caracterización y su desenlace desfavorable, apoyan la necesidad de profundizar en su conocimiento. Presentamos aquí los hallazgos clínico-biológicos de un paciente negativo para HIV, que fue diagnosticado de PEL peritoneal, originado en células $\mathrm{T}$ y no asociado a HHV 8, cinco años después de un trasplante renal.

Palabras clave: Linfoma de derrame primario (PEL). Linfoma no hodgkiniano.

\section{Introduction}

Primary effusion lymphoma (PEL) has been recently identified as a distinct subtype of non-Hodgkin lymphoma associated with infection of the neoplastic lymphoid cells by the Kaposi sarcoma-associated herpesvirus/human herpesvirus $8(\mathrm{HHV}-8)^{1,2}$. Primary effusion lymphoma has characteristic clinicopathologic features, including initial presentation as a lymphomatous effusion usually in the absence of a detectable tumor mass, occurs mostly in human immunodeficiency virus (HIV)-positive men, and has a morphologic structure that bridges large cell immunoblastic and anaplastic large cell lymphoma (ALCL) ${ }^{1,2}$. Neoplastic lymphoid cells are B cells with a peculiar phenotype. They usually lack surface immunoglobulin and B-cell-associated antigens such as CD19 and CD20 and express CD45, CD30, and antigens associated with late stages of B-cell differentiation such as CD138 ${ }^{1,2}$. Genotypic analysis of PEL has revealed clonal immunoglobulin gene rearrangements in all cases $^{1,2}$. We describe here a unique case among PELs arising in a HIV seronegative female, not associated with HHV 8 infection, after renal transplantation.

\section{Case report}

We report a case of a 27-year-old woman who was admitted to our hospital because of dizziness, headache and malaise. Five years earlier the patient had a renal transplantation due to chronic renal failure. From that period the patient was under immunosuppresion. She was HIV negative. On physical examination ascites was found but no peripheral lymphadenopathy or hepatosplenomegaly. Laboratory data on admission was as follows: $\mathrm{WBC}=6.7 \times 103 / \mathrm{ul}$, hemoglobin $=12.5 \mathrm{gm} / \mathrm{dl}$, platelets $=409 \times 103 / \mathrm{ul}, \mathrm{LDH}=144 \mathrm{U} / \mathrm{I}$, total protein $=3 \mathrm{~g} / \mathrm{dl}$, albumin $=1.2 \mathrm{~g} / \mathrm{dl}$, cholesterol $=217 \mathrm{mg} / \mathrm{dl}$, liver function tests, amylase and lipase were normal. HIV screen was negative. Peritoneal fluid showed albu$\min <1 \mathrm{~g} / \mathrm{dl}, \mathrm{LDH}=27 \mathrm{U} / \mathrm{I}, \mathrm{WBC}=1 / \mathrm{ul}$. Because all blood tests and CT scans of the abdomen and chest could not interpret patients' symptoms, an exploratory laparotomy was performed. During the operation 3lt ascitic fluid were removed but no other abnormalities were found except from a slightly thickened omentum and peritoneum from which biopsy samples were obtained. Cytological examination of the fluid, histologic interpretation of the excised specimens, immunophenotypic and molecular workup was indicative of primary T-cell effusion lymphoma. The patient received chemotherapy with endoxan, farmorubicin, oncovin and prezolon but three weeks later died due to postoperative complications.

\section{Results}

The direct smears from the ascitic fluid showed noncohesive large to very large lymphoid cells with 
abundant basophilic cytoplasm. The cells exhibited features that appeared to bridge large-cell immunoblastic and anaplastic large cell lymphoma. They contained large, pleomorphic, round to multilobated or kidney-shaped nuclei that often disclosed prominent nucleoli. A few cells showed eccentric nuclei, surrounded by a prominent clear perinuclear Golgi zone. Mitotic figures were abundant. Apoptotic neoplastic cells were noted. Histology revealed a diffuse infiltration of the fatty tissue by large lymphoid cells with abnormal nucleus, 1 to 2 prominent nucleoli and amphophilic cytoplasm. Mitotic figures were numerous. Immunohistochemically tumor cells were negative for cytokeratin (KL1, MNF116), and EMA. Most neoplastic lymphoid cells strongly positive for CD30, CD8, and CD3 (Figura 1), and showed weak

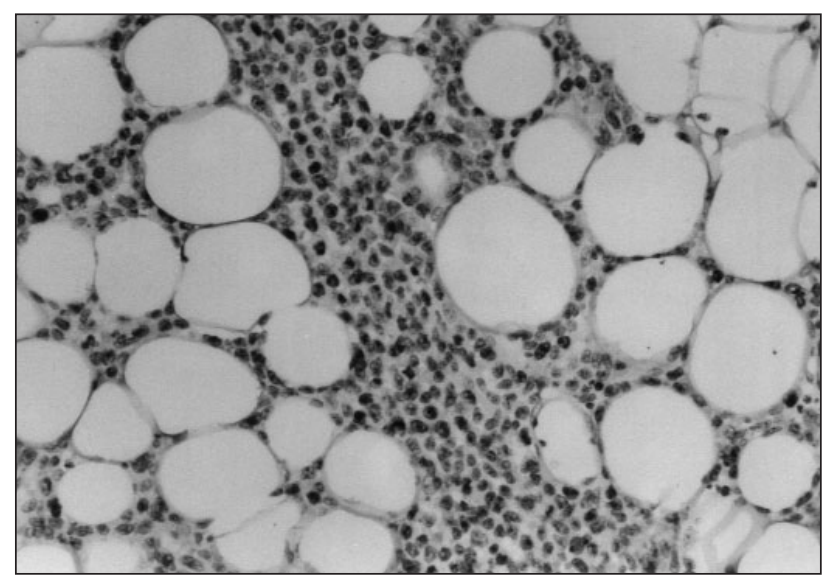

Figure 1. Positive staining of lymphoma cells for CD3. Tissue section, Immunostain X 200.

staining for CD45, whereas they were negative for CD19, CD20, and CD79a. The syndecan (CD138) was also absent except on a few mature plasma cells. Tumor cells did not express CD2, CD5, TIA1, or ALK1. The PCR analysis of T-cell receptor $\gamma$ chain gene rearrangement showed the presence of a predominant T-cell clone within an oligoclonal Tcell expansion. No clonal rearrangement of $\operatorname{IgH}$ chain gene was found. The search for EBV infection was negative both by immunohistochemistry and PCR analysis. No HHV-8 DNA sequences were detected by PCR neither. Patient's serum did not contain anti-HHV-8 antibodies. So, the diagnosis of primary effusion lymphoma with T-cell immunophenotype was established.

\section{Discussion}

PEL selectively involves the serous body cavities, occurs predominantly in immunodeficient patients and is frequently infected by human herpesvirus type-8 and Epstein-Barr virus. Deep immunosuppression promotes the emergence of lymphoproliferative disorders in patients undergoing solid organ transplantation. As with other high-grade lymphomas, prognosis is very poor with median survival of only a few months. Death is usually due to lymphoma.

In the present case, phenotypic and genotypic findings disclosed the T-cell origin of lymphoma cells. Indeed, neoplastic cells were negative for CD19, CD20, CD79a, CD138, and did not exhibit clonal IgH rearrangement by PCR analysis. By contrast, they strongly expressed $\mathrm{CD} 3$, and a clonal rearrangemnt of T-cell receptor $\gamma$ chain gene was found. Primary effusion lymphoma exhibiting a T-cell phenotype was reported only once, in an HIV-seropositive male patient (3). In the latter case, neoplastic lymphoid cells expressed various T-cell-specific antigens, including CD2, CD3, CD5, and CD7, and no B-cell markers, and both T-cell receptor and immunoglobulin gene rearrangements ${ }^{3}$. In our case, several features could be suggestive of ALCL. However, ALCLs commonly present with systemic disease, and isolated peritoneal effusion is uncommon. In addition, ALCLs are usually associated with a $\mathrm{t}(2 ; 5)(\mathrm{p} 23 ; \mathrm{q} 35)$ translocation that leads to an abnormal expression of ALK, a feature that was not observed in our case ${ }^{4}$. Moreover TIA1, a cytotoxic marker frequently detected in ALCL was not present ${ }^{4}$.

With a presentation as a peritoneal effusion and pleomorphic lymphoma cells identified in the fluid, the main diagnoses are anaplastic large cell lymphoma (ALCL) and PEL. A distinction between them is important because of the much better prognosis of the former. Similarities between ALCL and PEL may include similar morphologic features, CD30 expression and apparently null-cell immunophenotype ${ }^{5}$.

Features that favor PEL include known HIV infection, CD138 and MUM1 expression, and positivity for HHV8 and $\mathrm{EBV}^{5}$. Demonstration of a T-cell phenotype, absence of HHV8 and EBV from the tumor cells and ALK expression would favor an ALCL 5 . 


\section{References}

1. Carbone A, Cilia AM, Gloghini A, Capello D, Perin T, Bontempo D, Canzonieri V, Tirelli U, Volpe R, Gaidano G. Primary effusion lymphoma cell lines harbouring human herpesvirus type 8. Leuk Lymphoma 2000;36(5-6):447-456.

2. Fassone L, Bhatia K, Gotierrez M, Capello D, Gloghini A, Dolcetti R, Vivenza D, Ascoli V, Coco FI, Pagani L, Dotti G, Rambaldi A, Raphael M, Tirelli U, Saglio G, Magrath IT, Carbone A, Gaidano G. Molecular profile of Epstein-Barr virus infection in HHV-8-positive primary effusion lymphoma. Leukemia 2000;14(2):271-277.

3. Said JW, Shintaku IP, Asou H, de Vos S, Baker J, Hanson G, Cesarman E, Nador R, Koeffer HP. Herpesvirus 8 inclu- sions in primary effusion lymphoma: report of a unique case with T-cell phenotype. Arch Pathol Lab Med 1999;123(3):257-260.

4. Kinney MC, Kadin ME. The pathologic and clinical spectrum of anaplastic large cell lymphoma and correlation with ALK gene dysregulation. Am J Clin Pathol. 1999;111 (suppl 1):S56-S67.

5. Chan AC, Chan JK, Yan KW, Kwong YL. Anaplastic Large Cell Lymphoma Presenting as a Pleural Effusion and Mimicking Primary Effusion Lymphoma. A report of two cases. Acta Cytologica 2003, SEP-OCT;47(5):809-816.

Correspondence to:

Nikolas Papadopoulos

Assoc. Professor in Histology - Embryology

Democritus University of Thrace

Dragana, 68100 Alexandroupolis, Greece

E-mail: npapad@med.duth.gr 